\title{
SOCIAL IMPLICATIONS OF KNOWING YAHWEH: A STUDY OF JEREMIAH 9:22-23
}

Author:

Wilhelm J. Wessels ${ }^{1}$

\section{Affiliation:}

${ }^{1}$ Department of Old

Testament and Ancient

Near Eastern Studies,

University of South Africa,

South Africa

\section{Correspondence to:}

Wilhelm Wessels

e-mail:

wessewj@telkomsa.net

Postal address:

277 Eleanor Street,

Garsfontein, Pretoria

Gauteng, South Africa

\section{Keywords:}

wisdom; knowing Yahweh; justice; righteousness;

loving-kindness

\section{Dates:}

Received: 3 Aug. 2009

Accepted: 28 Oct. 2009

Published: 16 Dec. 2009

How to cite this article: Wessels, W.J., 2009, 'Social implications of knowing Yahweh: A study of Jeremiah 9:22-23', Verbum et Ecclesia 30(2), Art. \#83, 7 pages. DOI: $10.4102 /$ ve.v30i2.83

\section{This article is available} at: http://www.ve.org.za
(C) 2009. The Authors. Licensee: OpenJournals Publishing. This work is licensed under the Creative Commons Attribution License.

\begin{abstract}
In the brief passage of Jeremiah 9:22-23, wisdom, might and riches are explicitly rejected as reasons for boasting. The only true reason for boasting is if a person 'knows Yahweh'. In verse 23, this is linked with three other concepts: steadfast love, justice and righteousness. Jeremiah described the society of his day as corrupt in every sense of the word. People were stubborn, refused to acknowledge Yahweh and showed no signs of truly knowing him. They had, in fact, deserted the Torah of Yahweh. To know Yahweh has social implications. The rhetorical appeal of Jeremiah 9:22-23 to readers and hearers of this oracle is quite clear. To know Yahweh is not to claim to be wise or be the strongest or have the most possessions but to respond to Yahweh's way of acting. This implies an understanding of his loving-kindness and acting in a morally correct way.
\end{abstract}

\section{INTRODUCTION}

Jeremiah 9:22-23 (English translations 23-24) is a fascinating passage that focuses on the idea of knowing Yahweh. These verses form a unit that does not seem to link with either the previous section or the sections that follow. In most societies, qualities such as wisdom, might and riches are valued and it is these qualities that people often boast of. In this brief passage, these are explicitly rejected as reasons for boasting. Indeed, the only true reason for boasting is if a person 'knows Yahweh'. In verse 23, this 'knowing of Yahweh' is linked with three other concepts: steadfast love, justice and righteousness.

Scholars differ over the meaning of these two verses. Duhm (1903:97), on the one hand, regarded it as 'a harmless unimportant saying'. Brueggemann (1978:99), on the other hand, expressed the view that 'in categories of the Christian faith, Jeremiah here presents a theology of the cross in protest against a theology of glory'. The purpose of this article is, firstly, to search for an understanding of the two verses within the theological context of the Book of Jeremiah. This is a challenging endeavour that may not provide any conclusive results. The second purpose is to allow Scripture to create an awareness of and challenge us on what 'to know Yahweh' means for our particular societies. In this regard, readers have to answer for themselves what it implies with regard to their conduct.

\section{ANALYSIS OF THE TEXT: JEREMIAH 9:22-23 (English translations} 9:23-24)

That the Jeremiah 9:22-23 verses form a separate unit is clear from the following: Firstly, the previous section is concluded by a setuma ( 0 ) in the Masoretic Text (MT) and, secondly, the new passage in verse 22 is introduced with the messenger formula (פה אבמבר ידוזה) and concluded in verse 23 with a declaration that the preceding words come from Yahweh. This short section is again concluded with a setuma (0). The next passage - which begins with verse 24 - is introduced with a new formula that indicates a futuristic announcement. In short, verse 24 is clearly the beginning of a new section.

The passage presents us with an interesting structure that displays contrasting ideas. Three negatives (in verse 22) - wisdom, might and wealth - are contrasted by three positives - steadfast love, justice and righteousness. The pivotal point of the section is the phrase 'to understand and know Yahweh'. The verb 'boast' is repeated no less than five times; boasting of what does not matter is strongly contrasted with boasting of what does matter (verse 23). To demonstrate the structure, the MT is displayed as follows:

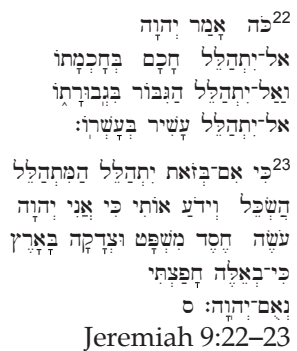

Arguments have already been presented as to why these two verses are regarded as a separate section, as a complete unit in themselves. It has already been pointed out that these verses are a prophetic oracle introduced with the messenger formula and concluded with a declarative statement that Yahweh endorses the oracle. This passage is therefore more than wise reflection on social matters; it makes clear in no uncertain terms that Yahweh demands obedience.

The messenger formula that introduces verse 22 (MT) is followed three times by the verb a thirdperson imperfect masculine singular verb, hitpael, jussive in meaning. The verbs are preceded all three times by ('do not'). The verb הלל in the hitpael means 'to boast'. 
Three groups of people are reprimanded and commanded not to boast of their wisdom, might (power) or wealth: the wise should not boast of their wisdom, the mighty not of their might and the rich not of their wealth. The thought of boasting is continued in verse 23 (MT) in the positive sense of the word, with an indication of what we may boast of. The introductory particle followed by $\mathrm{a}$, sets up the contrast (comparison) to the previous sentence - 'but'. ${ }^{1}$ The verb הלא is used twice in verse 23, first in the hitpael imperfect third person singular, jussive in meaning, followed by the hitpael participle masculine form of the verb. Two infinitive forms of the verbs (Hכל ( boasting, that is to show insight and knowledge of Yahweh. The particle is used here to introduce an objective clause following the verb 'to know' and has a causal purpose. It is then stated that

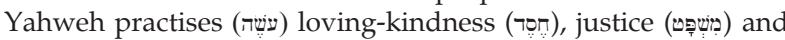

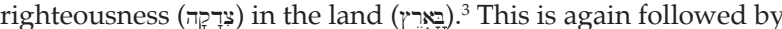
the particle (demonstrative) to state emphatically that Yahweh delights in the triad of matters referred to in the preceding part of the sentence. The verb חפק (qal first person singular) goes with the particle $\exists$, expressing what the satisfaction lies in. Verse 23 (MT) closes the passage with the declarative expression that Yahweh confirms the oracle. The focus in verse 22 is on people and, in verse 23, on Yahweh (first person singular).

Verse 22 describes certain categories of actions that people carry out but should not carry out. In verse 23 , we are informed what Yahweh does on earth, things that are good because he delights in them. Contrast is therefore created. The two verses under discussion use rhetorical devices, such as the repetition of verbs (הלל), triad patterns and successive repetitions of the same consonants in words used as adjectives followed by

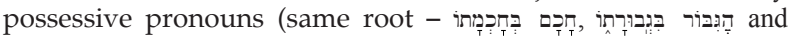

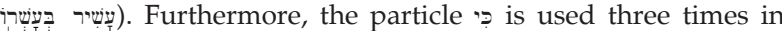
verse 23 for different purposes. Finally, verse 22 commences with the announcement that the oracle to follow is from Yahweh and verse 23 concludes by declaring, again, that the oracle is from Yahweh. In the discussion to follow, focus is on the three groups of people (the wise, the mighty and the wealthy) and on the three practices of loving-kindness, justice and righteousness (as referred to in the Book of Jeremiah).

Jeremiah 9:23 (23-24) is regarded by many commentators as poetry (McKane 1986:212-213; Rudolph 1968:69; Thompson 1980:318-319; Weiser 1969:83-84); one can, at the least, find a certain rhythmic prose in this unit (Lundbom 1999:570). These two verses are also well balanced through contrasting triads: 9:22 - wisdom, strength and riches - and 9:23 - steadfast love, justice and righteousness. These two sets of triads stand in contrast with each other. This is a deliberate contrast and clearly has the function of indicating where the focus in this passage lies. There is also the contrast of people, on the one hand, and Yahweh, on the other hand.

\section{TEXT AND CONTEXT}

Thus far, matters have been relatively clear. It is obvious that, in Jeremiah 9:22-23, we are dealing with a separate unit and that this unit displays a clear structure that supports the understanding of the passage. This is discussed later in this article.

Less clear, as far as the entire passage is concerned, is the context. There are no obvious links with the previous passage or the following passage. This is why some scholars regard it as an editorial interpolation that was inserted during the formation of

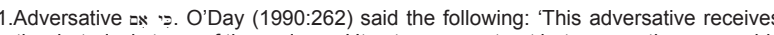
the rhetorical stress of the pericope.' It sets up a contrast between anthropomorphic boasting and theocentric boasting.

2.Saebo (1976:824) stated the following: 'Die Hauptbedeutung des Verbums lässt sich am besten durch "einsichtig, klug sein» wiedergeben.' He also stated the following: 'Doch liegt öfter das Gewicht auf dem Akt des aufmerksamen Hinsehens, des Wahrnehmens und Achtgebens, wodurch man "einsichtig» wird.'

3.Stulman (2005:106) admitted that we can translate this either as 'in the earth' or as 'in the land'. He preferred, in this context, 'in the land', since it refers to nationa boundaries.
}

the text (Carroll 1986:247-249; Duhm 1903:97; McKane 1986:212213). Other scholars, however, regard the passage as 'echt' ('true') Jeremian (Rudolph 1968:69) and construct a case to show how these verses fit into the context of the time (Huey 1993:121-122; Jones 1992:169-170; Schmidt 2008:211-213; Thompson 1980:318; Weiser 1969:83-84)

An important issue that one should not lose sight of is that the Jeremiah text is an interpreted text. By that I mean that the various prophetic sayings and collections of the prophet's proclamations were assembled and structured with deliberation and that deliberation, in itself, is an act of interpretation. The purpose was certainly to preserve Jeremiah's prophetic utterances for future generations but even more so to show relevance and to explain why the editor's community was undergoing certain experiences. The Jeremiah textual collection, according to this line of argument, is therefore a reflection on the prophetic proclamation of Jeremiah in pre-exilic times and on appropriation to a new context. This context is of those in exile, living far away from their homeland, temple and social and religious security, all of which are in danger of becoming culturally extinct. It is important that these people do not seek for meaning - in exile - in conventional wisdom, power and riches (Stulman 2005:105). These have failed as a means of security in pre-exilic times and cannot replace their relationship with Yahweh. Only in such a relationship can they grow in their knowledge of what Yahweh requires.

Research shows that the composition of the book of Jeremiah is extremely complicated and that the text, as we now have it, has a long history (Carroll 1986:38-55). ${ }^{4}$ For the purposes of this article, it is not necessary to discuss this in detail. What is clear, from the experience of working with the text of Jeremiah and, for that matter, with other texts in the Masoretic collection, is that whoever was responsible for the collection and structuring of the biblical text did so deliberately. There has to be a reason for the placement of Jeremiah 9:22-23 in its current position, whether it is clear to us or not. Although we might not be able to conclude with certainty why the passage was placed where it now stands, it is worth suggesting possibilities (contra Carroll 1986:248-249). Note that Rudolph (1968:69) believed that these two verses relate to Jeremiah 2:8, 4:22, 9:2, 5 and 22:16.

\section{Literary context of Jeremiah 9:22-23}

As far as the literary context of Jeremiah 9:22-23 is concerned, verses 22 to 23 do not seem, at first sight, to link with the previous or the following sections. Scholars have, however, tried to suggest possible literary contexts. One such suggestion is to work with 4:1-4 and 9:22-25 as a unit (Lundbom 1999:569-570). Another suggestion is to regard Jeremiah $8-10$ as the context for the interpretation of 9:22-23 (Baumann 2002:77-78).

Carroll (1986:86) believed that Jeremiah 9:22-23 forms part of the section of Jeremiah 7:1-9:26, which consists of a collection of individual poems. In his discussion on the formation of the Book of Jeremiah, Schmidt (2008:34) postulated that some sections of the Jeremiah text were added to the older collection, Jeremiah 1 to 6 , at a later date. He regarded chapters 8 to 9 , for example, as part of this later addition but dated these additions before the downfall of Jerusalem in 586 BCE (certainly not much later than this). His reasoning is that the focus of these passages is on complaints against the city of Jerusalem. If one accepts his point of view, it does, to some extent, create a social context, albeit vague, of a time when the reasons for the imminent exile became clear; there is a steady build-up and a confluence of the reasons why Judah is heading for disaster.

For the purpose of this article, I am interested in the first oracle, which is in 9:22-23 (23-24). When one compares this oracle with the oracles in 4:2 and 4:4, certain keywords - which are 
important to note - can be noticed from time to time. In $4: 2$, we find the words 'in justice and in righteousness they shall boast' and, in 4:4, there is a reference to circumcision; the words 'they shall boast' also appear. Lundbom (1999:569-570) indicated that 4:1-4 and 9:22-25 (23-26) act as a frame to the collection that we find in 4:5-9:21 (22).

Another group of scholars regards Jeremiah 7 to 10 as a literary unit. Diamond (2003:561-564) regarded Jeremiah 7:1-10:25 as a collection that consists of a group of texts under the rubric Singing the death of Jerusalem (8:4-23; 9:1-10, 16-21; 10:17-22). This collection also consists of a group of texts under the rubric Dismantling the temple: Prophetic sermons and ideal worshippers (7:1-8:3; 9:11-15, 22-25). According to Diamond, the passage under discussion in this article forms part of this last-mentioned group of texts. Diamond said that

To save Yahweh and his prophets from such aporia and fend off the symbolic abyss so generated, the composition intervenes with prose speeches (7:1-8:3), commentary $(9: 11-15,22-25)$ and liturgical proclamation $(10: 1-16,23-25)^{5}$.

(Diamond 2003:562)

According to Stulman (2005:88), section 8:4-9:25 talks about Yahweh's reasons for judging his people for their neglect of the law and resultant wrongdoing. He summarised the content of Jeremiah 7 to 10 as follows: '.. a daring assessment of Judah's systems of worship and the false sense of security they engender. The Jerusalem temple is the centrepiece of this critique.' The cycle of laments in Jeremiah 8:4-9:26 does not mention the temple but Stulman (2005:89) made the important observation that these laments were read in synagogues to commemorate the destruction of the temple in $587 \mathrm{BCE}$ and, much later, in $70 \mathrm{CE}$.

Also of importance is that these two verses (9:22-23) are presented to us as a prophetic oracle. They commence with the messenger formula of 'thus says Yahweh'. Lundbom (1999:570) pointed out that the messenger formula is a clear indication that the passage is not 'simply a piece of reflective wisdom' but a true prophetic oracle. He continued by saying that, although one cannot claim beyond any doubt that this passage comes from Jeremiah, it clearly fits in with the spirit of his thinking and speaking.

From what I have said so far, it is obvious that it is difficult to show formal links between our passage and the previous section in chapter 9. The passage in Jeremiah 9:22-23 (23-24), in the context of the day, serves the function of softening the judgement oracle in verse 21 - it mentions Yahweh's lovingkindness, justice and righteousness. It is difficult, however, to determine whether this 'softening effect' was intentional or not. It does, however, remain important for readers of the Jeremiah text to take note of who Yahweh is and how he acts.

\section{Jeremiah 9:22-23 and wisdom}

Another question that needs attention is the influence of wisdom in the book of Jeremiah. In this regard, Baumann (2002:77) viewed Jeremiah 8 to 10 as the context within which 9:22-23 should be interpreted. Although these two verses are, first and foremost, a prophetic oracle, this does not preclude the influence from wisdom circles on this passage. ${ }^{6}$

It is important for the purpose of this article to place Jeremiah 9:22

5.Stulman (2005:86-89) had a similar idea regarding Jeremiah 7 to 10 as a literary unit. He divided these chapters into $7: 1-8: 3$, which is a prose collection concerning abuses when Judah, as a people, worships together, and 8:4-10:25. This last section consists mainly of poems relating to the disaster that is about to befall Judah.; a sense of sadness is expressed in this section. The second section talks about Yahweh's justification in judging his people for wrongdoing (8:4-9:25). In 10:1-16 a hymn of praise celebrates Yahweh's power and sovereignty, also contrasting it with the powerlessness of the gods of the nations. The section 10:17-25 consists of several poems revealing, as Stulman said, '. panic, and an urgency to evacuate the land before the night falls' (2005:88).

6.Schreiner (1981:73) stated that 'ein weisheitlicher Spruch' probably forms the basis of this reprimand by Yahweh. Maier (2002:232), following Duhm, Carroll and Wanke, said that 'Jer 9, 23 ist eine späte weisheitliche Reflexion.' Schmidt (2008:212) regarded the style of the passage as wisdom, and the concepts of loving-kindness (loyalty), justice and righteousness belonging to wisdom circles. in the context of the book of Jeremiah. Jeremiah 9:22 criticises the boasting of the wise, the strong and powerful and the wealthy. In Jeremiah 4:22, the people of God are regarded as wise - wise people being the first group of people addressed in Jeremiah 9:22 - in that they have plenty of experience in committing evil. In Jeremiah 8:8 and 9, the wise are those who have the law but who regard their own wisdom as superior to the Word of Yahweh. According to Jeremiah, disaster will strike them. Certain skilled people are also, however, referred to as wise people (Jr 10:9). Jeremiah 18:18 speaks of three different groups of people known in Judean society to speak divine words. There is a reference to the priests, who explain the law, to the wise, who advise people, and to the prophets, who are known for their divine oracles. These wise people may have been the 'elders' in Judean society (Carroll 1986:378). In this context, however, these so-called wise people are some of the people who are plotting against the prophet. Jeremiah also refers to Yahweh's wisdom in 10:7. Compared with Yahweh, there is nobody among the nations or kingdoms who can match his wisdom. The passages referred to in Jeremiah are characterised by negative undertones. It is quite clear that trust in human wisdom does not bring about desired results but, instead, leads to injustice and the downfall of people.

In fact, in the book of Jeremiah, we have a differentiated understanding of wisdom, which includes both its positive and its negative aspects. On the whole, however, the wise are objects of Jeremiah's criticism. The one exception may be the women in mourning (Jr 9:16).

Baumann (2002:71) remarked that we should not regard Jeremiah 9:22-23 as a general denouncement of wisdom, might and wealth. We should, instead, regard the passage as a subtle criticism of specific groups of people that Jeremiah had in mind, using vocabulary that they would recognise. It is clear in Proverbs that wisdom is, first and foremost, to be associated with Yahweh; he is the source of all wisdom and all human wisdom is relative to his wisdom.

The second group of people addressed in Jeremiah 9:22 is the

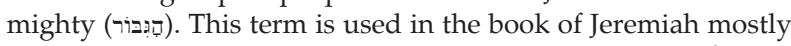
in a military context (Kühlewein 1971:399-402); besides referring to physical strength, it can also be used to depict military and political power (1 Ki 15:23; Is 11:2; cf. O'Day 1990:261). The term is used differently in the book of Proverbs. There it is used in comparison with those who experience longevity (Pr 16:32) and with the wise (who are superior to the mighty - Pr 21:22).

The third group of people addressed in Jeremiah 9:22 is the

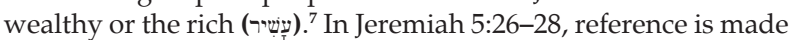
to evil people who are wealthy simply because they have abused the widows and the poor; Jeremiah says that their wealth will not last. The reference in Jeremiah 17:11 is also to wealth obtained by unjust means.

Baumann (2002:74) concluded that, both in the book of Jeremiah and in the book of Proverbs, boasting is regarded as self-glorification (Selbstüberhebung) and should be regarded as falsehood.

We also find a triad in verse 23. In the book of Jeremiah, this triad has a positive connotation. The concept of justice and righteousness, in particular, is highly regarded in the book of Jeremiah. ${ }^{8}$ Wolff (1993:287-288) argued that this word pair

7.In the book of Proverbs, wealth is often regarded in the positive sense of the word $(10: 4,11,16 ; 10: 15 ; 14: 20)$. There are, however, verses that display a critical attitude towards wealth ( $\operatorname{Pr} 11.28)$. In this regard, there is reference to the illegal gaining of wealth $(10 \cdot 2 ; 21: 6 ; 28: 6)$. Righteousness is also regarded as being of higher worth of wealt (10:2;21:6:28:6). Rightous ress is also is than wealh (11:4). The same applies to a good reputation (22:1). What is perhaps important to note is that weath is not necessanily associated with wisdom. On the contrary, in the book of Proverbs, wisdom is always associated or linked with poverty $(28: 11)$. It is Yahweh who is the true source of wealth $(10: 22)$ and, before him, the poor and the wealthy are equal (22:2; cf. Baumann 2002:272)

8.The combination עשה משפפט וצדקה appears in Jeremiah 9:23;22:3, 15; 23:5; $33: 15$ 
originated from Israelite 'Spruchweisheit' (Pr 18:8; 21:3; 1:3; 2:9). The biggest defect or deficiency in Israel was that the justice that people received from Yahweh (8:7) was not carried out as it should have been, that the requirement of justice was not being fulfilled. The people of Yahweh and particularly the society's leaders violated justice and righteousness and therefore violated the Torah of Yahweh. Contrary to this, 'loving-kindness' (70ח) is not a human virtue but an attribute of Yahweh $(16: 5 ; 31: 3 ; 32: 18$; 33:11).

In the book of Proverbs, the phrase 'justice and righteousness' occurs many times, equalling the number of references to the knowledge of Yahweh and wisdom. Justice and righteousness are also often posed as opposites to godlessness ('wicked people'

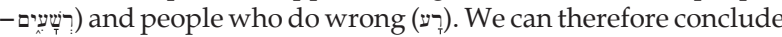
that, both in the book of Proverbs and in the book of Jeremiah, justice and righteousness are held in high regard. It is only in Jeremiah 9:23, however, that we find the triad in this sequence

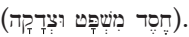

As I have already stated, we find elements in Jeremiah 9:2223 of both wisdom and prophetism combined. The biggest concentration of references to the wise is in Jeremiah 8 to 10 (see my comments on content and context). ${ }^{9}$ I agree with Baumann (2002:77) that 9:22-23, in terms of Jeremiah 8 to 10 , should be regarded as an understanding of what a wise way of living (doing) entails. The negative portrayal of human wisdom relates directly to the people's perversion of the Torah. Human wisdom, which so often fails, is directly contrasted with Yahweh's social and universal wisdom (Jr 10:12).

\section{SYNTHESIS AND RELEVANCE}

In the Jeremiah 9:22-23 prophetic oracle, the words are addressed to three different groups of people in society.

The first group comprised those who boasted of their wisdom; ${ }^{10}$ whether other people agreed with them or not, these people were a distinguished group of people in society.

The second group comprised the mighty, the people with power. Again, this was a recognised group of people in society.

Then there was a third group, the rich. This group comprised people with material means. These people were probably literate, influential people who dominated society at the time. Intellectuals, along with the powerful and the rich, always form the upper echelons in any society. They were the ones envied by many and, at the same time, the ones on whose mercy ordinary people depended.

In many prophetic passages in the Old Testament, these, however, were the very people whom the prophets denounced. We need to remember that most of these people occupied important positions in a king's administration and in other places where decisions were made; their words and actions had a decisive bearing on the existence of ordinary citizens and much was therefore expected of them. However, they frequently failed to discharge their duties.

Jeremiah, for one, expected these people to know Yahweh's law and the stipulations of the covenant (ch. 5). Jeremiah 9:22-23 is, in fact, a criticism of these very people because they relied

(footnote 8 continues...)

and 4.2 without the verb.

9.Baumann presented an extensive argument, taking Jeremiah 8-10 into account, that we are dealing with a new profile of wisdom in Jeremiah. She said that '[a] new wisdom profile is developed here: Instead of the self-boasting of the wise, the mighty and the wealthy, recognition is now given to the cosmic power of Yahweh which would serve as basis or foundation for "menschlichen Selbstruhms"' (Bauman 2002:77) Although she argued her case thoroughly, the link that she drew between $2002.77)$. Although she argued her case that minly, the in

10.Oosterhoff (1990:308) did not regard wise people to be wisdom teachers but advisers to the king who were convinced of the accuracy of their advice, boasting about it and tolerating no opposition to their views (Jr 18:18) entirely on false sources of security. This threatened to disrupt Judean society because Judah was neglecting her covenantal obligations. Worse still, it threatened the identity of the members of this society as Yahweh's covenant people (O'Day 1990:266). It frustrated Jeremiah because these people lacked real knowledge of what Yahweh expected of them as leading figures in society.

The way that they are addressed in verse 22 reveals that their boasting does not please Yahweh by any means. From the fact that the counter verse, verse 23, places emphasis on other issues that impact heavily on the lives of ordinary people, one can deduce that verse 22 is very much a criticism of Judah's leaders. In other words, the unit is not simply two sets of verses that bear no relation to each other. It is no coincidence that verse 23 emphasises the relational aspects of loving-kindness (loyalty), justice and righteousness. Whereas the achievements in verse 22 are solely human achievements with benefits mainly for those who have gained and possess these things, verse 23 describes the triad of deeds that impacts on everyone in the land as being deeds that Yahweh himself has carried out. They are, in other words, godly deeds. The combining of the two verses implies that Yahweh does not delight in the boasting of those in the upper echelons of society on account of their being wise, powerful and wealthy; on the contrary, he delights in loving-kindness, justice and righteousness. As O'Day said:

Distorted sources of human identity are superseded by the true sources of the community's identity that are grounded in God's faithful character and acts (עי). God's steadfast love, justice and righteousness are the sources of identity and well-being, of security and governance.

(O’Day 1990:262)

Besides the two verses stating who Yahweh is and how he acts, we should also hear prophetic criticism. The people (the leaders in particular) have failed Yahweh and each other in terms of the concepts referred to previously. Schmidt (2008:213) made an important point when he said: 'In der Gegenwart erfolgen weder das Erkennen noch das Handeln entsprechend. Solche Aspekte bilden wohl den Grund der Einfügung des Wortes, die Voraussetzung für des Mahnung, dan auch die Hoffnung.' The people of Judah have failed in confession and in their actions in terms of what the God of the covenant expects of them. They therefore deserve to be reprimanded and punished but, at the same time, the hope remains that, in the future, a ruler who fulfils the expectations of loyalty, justice and righteousness so needed in society will arise (Jr 7:32; 23:5, 7)

The term strongly emphasises a relationship in which one party acts in a beneficial way towards the other party in that relationship. Normally, the exercise of unequal partners, where the more powerful partner or the partner with more means has the obligation to respond to the partner in need. This help should be rendered in a spirit of love and care and should be voluntary (Houston 2006:42). ${ }^{11}$ In the Old Testament, this term should be understood within the context of the covenant between Yahweh and his chosen people. It reflects a mutual commitment between the two parties; there is a sense of reciprocity embedded in this term. By acting in love, fidelity and care in the relationship, the beneficiary is enticed to respond in a similar fashion (Brueggemann 2002:127). In regard to the covenant, Yahweh, as the Superior Power, exercises (fidelity, loving-kindness, loyalty, steadfast love) towards the lesser party. ${ }^{12}$ The term has a great deal to say about the character of Yahweh and his attitude to his people (Thompson 1980:319). It is a term that not only expresses an emotion but is also providential

11. Houston (2006:41-47) referred to the term within the context of his discussion of the patronage system.

12.Stoebe (1971:603) referred to Glueck, who regarded this concept not as friendeliness but as 'eine Verhaltensweise, die aus einem durch Rechte und Pflichten bestimmten Lebensverhältnis (Mann-Frau; Eltern-Kinder; FürstUntertanen) herrühre'. When expressed by Yah of promises relating to the Stoebe (1971: 600-621) indicated in his discussion, the context should determin the meaning of the concept, whether it means 'love, loyalty, faithfulness' etc. 
in nature in that it specifically addresses the needs of the other party in the relationship (Clark 1993:267). In this instance (9:23), it is Yahweh who practises Judah will respond to Yahweh's attitude by being loyal to him and kind to others (Lundbom 1999:572).

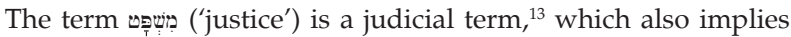
that the people responsible for justice are educated people. Again, it is, in a sense, a superior taking care of the rights of an ordinary person. In verse 23 , it is said that Yahweh exercises

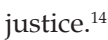

The term צִדִ ('righteousness') is a more regular term for doing what is right and cannot be used to support the argument of a superior's action towards an ordinary person. Stulman (2005:106) said the following of righteousness: " Righteousness" alludes to moral symmetry, integrity, the absence of duplicity, and ethical governance.' In practice, justice and righteousness imply that people's rights (in particular the rights of the oppressed, the poor and the vulnerable) should be restored and that those who transgressed should be punished. Thompson (1980:320) remarked that the term 'righteousness' in several passages is synonymous with 'deliverance' or 'salvation'. ${ }^{15}$ Leaders are expected to ensure that justice prevails among the people in their community. Yahweh (verse 23) does exactly this and regards it as important. It seems not too far-fetched to regard verse 23 as criticism of society's elite for not acting as superiors should. Yahweh, the One who has to be revered and acknowledged as the God of Judah and Israel, practises justice and righteousness but the elite do not. Instead, they boast of their own achievements, achievements that do not bring any benefits to the people in their society. Their selfish and self-serving acts are contrasted with acts that serve and benefit others (Brueggemann 1998:101). ${ }^{16}$

At the beginning of this article, when I referred to the structure of the passage, I said that the pivotal point is the phrase

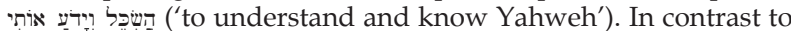
boasting of undesirable things, the advice in verse 23 is that, if someone really wants to boast, he should boast of his knowledge of Yahweh. ${ }^{17}$ 'To know Yahweh' and 'to have knowledge of Yahweh' are phrases that we often come across in the book of Jeremiah. In 4:22, for example, the references are 'to know me [Yahweh].' In 9:2 and 9:6, this is expressed in the negative of 'they do not know me [Yahweh].' In 5:4 and 5, it is said that they do not know the way of Yahweh, they do not know the requirements of

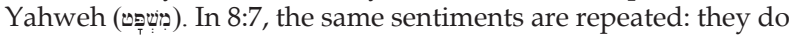
not know the requirements (משפטי) of Yahweh. It therefore seems that knowledge is about who Yahweh is and what he requires. In Jeremiah 9:23, the verb 'to know' has Yahweh as the direct

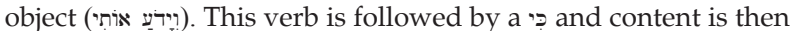
given to what it means to know Yahweh. It is further stated that all of this is happening on earth or in the land; in other words, in the space where people live. Loyalty, justice and righteousness therefore have ethical implications. True understanding and knowledge of Yahweh, according to verse 23, entail fidelity (loving-kindness), justice and righteousness.

While the members of the elite or upper class of Judean society boast of their human achievements, verse 23 opens up boasting

13.Thompson (1980:319) said that it '... covers a wide variety of action which both accompanied and followed court proceedings. Not only was a verdict pronounced, but a sentence was carried out'.

14.Oosterhoff (1990:309) was of the opinion that Yahweh exercises justice on earth both in the fulfillment of his promises to those who worship him (Ps 11:7; 33:4; $36: 11 ; 51: 16 ; 71: 15 ; 103: 6)$ and in his retribution towards those who hate him (Ps $97: 2 f$; Is $5: 16 ; 10: 22$ )

15.Jr 5:1; Is 5:7; 28:17; Hs 2:21 (Eng 19); 10:12.

16.According to Stulman (2005:106), what we have in these two verses is a move from royal/urban values (conventional wisdom, military power and commercial interests) to values associated with and treasured in village set-ups (loyalty, generosity and integrity).

17.Schmitz (1971:395) said the following about this knowledge: 'Experience becomes a reality in a relationship based on familiarity with the person or things known.' This a reality in a relationship based on familiarity with the
view was also expressed by Schottroff (1971:686). to anyone who claims to have knowledge of Yahweh. These terms are relational and have to do with a proper attitude and fair practices. I have argued that it was usually those in elite or privileged positions that were expected to act with sound judgement and fairness. These were the people who were supposed to take care of people in lesser positions, people such as the poor, widows and orphans and various other oppressed people. Knowledge of Yahweh should result in the leaders having an attitude of care towards others and ensuring that justice prevailed for everyone in society (Brueggemann 1994:66).

The rhetoric of Jeremiah 9:22-23 is important and should not escape our attention. Verse 22 tells us plainly what is unpleasing to Yahweh; the three groups of people mentioned should not boast of their human achievements. In contrast, verse 23 does not give a direct order or a specific command about how people should act. Instead, the people who boast are simply told that they should boast because they know Yahweh. And this knowledge implies an understanding of who Yahweh is and what he does. He exercises loving kindness, justice and righteousness. This is one of his traits. ${ }^{18}$ It is then further stated that Yahweh delights in these characteristics. The implied message in the rhetoric of this passage is this: if people know Yahweh, they will exercise or practise these things, the things in which Yahweh delights.

The implication of this is that anyone - in any situation at any time in history - who claims to know Yahweh will feel obliged to act like Yahweh does. To have knowledge of Yahweh means to understand the moral obligation to live as an ethically responsible person in society. The stability and welfare of a society depend on the commitment to and practice of such concepts. The truth of the matter, however, is that, in our societies with their focus on individuality and commoditisation, there is a struggle to maintain these crucial features (Brueggemann 2002:127).

We need to remember that the terminology of loving-kindness, justice and righteousness, as used in the book of Jeremiah, presupposed a certain understanding within the Judean context of the day. The two concepts of justice and righteousness appear in this combination several times in the book of Jeremiah. ${ }^{19}$ The way in which the expression 'justice and righteousness' is used in the book of Jeremiah shows the two words to be almost synonymous in meaning. Taken separately, each of these concepts has somewhat different meanings but, when used, as it were, in combination (as in the book of Jeremiah), it is not necessary to distinguish between them. Combined, the two concepts (justice and righteousness) express what social justice in society entails. ${ }^{20}$ They provide a comprehensive understanding of what is meant by 'just' and 'ethical' (Maier 2002:232). Justice and righteousness refer to an attitude that results in fair practice in the treatment of others in society, particularly the vulnerable and those without legal status. Those who know Yahweh will see that justice prevails in society.

Brueggemann (1997:736-737) differentiated between two types of justice, the one called 'retributive justice' and the other 'distributive justice.' The first form of justice concerns reward on performance, whilst the second form concerns the willingness to share

...social goods and social power so as to avoid unequal and potentially destructive distribution of resources. Yahwistic justice, and the knowledge of Yahweh are realized when the community freely practices such economic and social generosity and commitment.

(Soza 2005:142)

'Distributive justice' implies that the focus of wealth and material

18.Stulman (2005:105-106) said that this knowledge of how Yahweh acts is creedal and relational. The triad in 9:23 defines Yahweh's character.

19. The combination עשיה מששפט וצרקה appears in Jeremiah $9: 23 ; 22: 3,15 ; 23: 5 ; 33: 15$ and $4: 2$ without the verb. Wolff $(1963: 287-288)$ argued that the word pair originated from Israelite 'Spruchweisheit' ( $\operatorname{Pr} 18: 8 ; 21: 3$; also $\operatorname{Pr} 1: 3 ; 2 \cdot 9$ ).

20.Some scholars regard the use of the two concepts in combination in prophetic literature as exilic or post-exilic (Maier 2002:232). Maier said that 'Jer 9:23 ist eine späte weisheitliche Reflektion' (2002:232). 
goods is not on what the individual possesses but on everybody in the community sharing the resources available to that community on terms that are deemed fair. This, again, would be one of the results of knowing Yahweh. It was particularly in this regard that the leadership of Judean society in Jeremiah's time failed. This, in turn, testified to the fact that the leaders of Judah lacked any knowledge of Yahweh.

Justice and righteousness were not simply impressive-sounding concepts but they also had concrete meaning and specific requirements. The way in which the expression justice and righteousness' was used in Jeremiah meant that the poor and the marginalised should be protected. Judah's leaders were responsible for seeing that all this did, in fact, occur (Jr 5:1-6). Furthermore, the king and his officials should safeguard and care for those who were in danger of being exploited (through economic oppression - Jr 22:1-5). Justice and righteousness also prohibited robbing people of their freedom and shedding innocent blood (Jr 22:16; cf. Maier 2008:27). ${ }^{21}$ This brings us back to Jeremiah's complaint: that society lacked a true knowledge of Yahweh and his covenant stipulations. ${ }^{22}$ The leaders and the people failed morally and Jerusalem would therefore fall into the hands of her enemies, the Babylonians.

According to Houston (2006:96-97), we should not regard the criticism of the prophets as structural criticism. Israelite and Judean societies, like contemporary societies, consisted of different classes (such as the poor and the rich). According to Houston, the prophets did not denounce the fact that the poor and the wealthy existed side by side but that some of the wealthy obtained their wealth by exploiting others. To prophets like Jeremiah, what was wrong was that the powerful took advantage of those who were at their mercy.

I do not, however, agree with Houston's statement that the prophets '... have nothing to say about positions held by individuals, the powers of the state or the legitimacy of the class structure' (Houston 2006:96). Jeremiah condemned the false sense of security in the royal temple ideology promoted by the upper classes, who supported the king and his administration - to their benefit. Using forced labour for state projects and turning a blind eye to land exploitation by wealthy people in the cities seems to me a serious misuse of the structures and positions of power. Jeremiah was an enemy of the king (and therefore the state) and all those who sought the favour of the king. In exchange for their support, the kings of Judah granted the exploiters the freedom to commit injustices. Houston did, however, draw an important conclusion when he remarked as follows:

Through the prophets we have learnt to understand social relationships as governed by morality as interpersonal relationships are - that social relationships are moral relationships, and hence that we can speak of social justice.

(Houston 2006:97)

Although prophets such as Jeremiah speak from a religious context, it is in the political and social contexts (including economics) that the moral transformation needed should take effect. True knowledge of Yahweh would bring the shift in focus from human achievements to an appreciation of true values.

\section{FINAL REMARKS}

The first aim of this article was to come to an understanding of Jeremiah 9:22-23 within its literary and social context. Throughout the preceding chapters (1-7), Jeremiah makes it clear that Judah is disobedient and disloyal to Yahweh. Chapter 8 shows the claim of the so-called wise to know the Torah to be false..$^{23}$ Jeremiah

21. Houston (2006:88-93) regarded the following as acts of oppression: Bloodshed, violence and coercion, extortion, unjust gain, loss of freedom, perversion of right and indulgence at the expense of the poor.

22.Yahweh's reprimands and judgement of Judah's actions of injustice should, according to Houston (2006:84), be understood within the framework of faithfulness to Yahweh, his covenant and its commandments. describes the society of his day as corrupt in every sense of the word. People are stubborn, refuse to acknowledge Yahweh and show no signs of truly knowing him. They have, in fact, deserted the Torah of Yahweh. There are no wise people left in Judean society, except the women in mourning, who are wise enough to know that they should weep over Jerusalem and its impending misery. In this context, Jeremiah 9:22-23, which uses vocabulary and ideas relating to wisdom, is presented as a divine oracle. The thrust of the oracle is a scathing criticism of Judah and Jerusalem for boasting of things that provide false security (Brueggemann 1998:101). True security consists of knowing Yahweh, which entails living according to the covenant stipulations. This is the solution to Judah's problems but, at the same time, its downfall, because its leaders have proved to be moral failures. As the last part of chapter 9 states, Israel has an uncircumcised heart, meaning that she is disloyal to Yahweh, her covenant partner.

It is important to observe that there are similarities and even strong resemblances in terms of vocabulary, concepts and even metaphors between the book of Jeremiah and some of the wisdom passages in the Old Testament. We should not, however jump to the conclusion that the passage in Jeremiah 9:22-23 is a wisdom text. The most it shows is what a prophet such as Jeremiah regards as a wise way to live as Yahweh's people: with insight, humility and obedience (cf. also Mi 6:8).

The second aim of this article was to explore the social implications of knowing Yahweh. The rhetorical appeal of Jeremiah 9:22-23 to readers and hearers of this oracle is quite clear. To know Yahweh is not to claim to be wise or to be the strongest or to have the most possessions but to respond to Yahweh's way of acting. This implies an understanding of his loving kindness and acting in a morally correct way. It means feeling morally obliged to act justly and to ensure that justice prevails. In short, knowing Yahweh has social implications.

\section{REFERENCES}

Baumann, G., 2002, 'Jeremia, die Weisen und die Weisheit. Eine Untersuchung von Jer 9, 22f', Zeitschrift fur die Alttestamentliche Wissenschaft 114, 59-79.

Brueggemann, W., 1978, 'The epistomological crisis of Israel's two histories (Jer. 9:22-23)', in J.G. Gammie, W.A. Brueggeman, W.L. Humphreys \& J.M. Ward (eds.), Israelite wisdom: Theological and literary essays in honor of Samuel Terrien, pp. 85-105, Scholars Press, Missoula.

Brueggemann, W., 1994, A sociological reading of the Old Testament. Prophetic approaches to Israel's communal life, Fortress Press, Minneapolis.

Brueggemann, W., 1997, Theology of the Old Testament. Testimony, dispute, advocacy, Fortress Press, Minneapolis.

Brueggemann, W., 1998, A commentary on Jeremiah. Exile $\mathcal{E}$ homecoming, Eerdmans, Grand Rapids.

Brueggemann, W., 2002, Reverberations of faith. A theological handbook of Old Testament themes, Westminster John Knox, Louisville.

Carroll, R.P., 1986, Jeremiah. A commentary, SCM (OTL), London.

Clark, G.R., 1993, The word hesed in the Hebrew Bible, Sheffield Academic Press (JSOT SS 157), Sheffield.

Diamond, A.R.P., 2003, 'Jeremiah', in J.D.G. Dunn \& J.W. Rogerson (eds.), Eerdmans commentary on the Bible, pp. 543559, Eerdmans, Grand Rapids.

Duhm, B., 1903, Das Buch Jeremia, JCB Mohr, Tübingen.

Houston, W.J., 2006, Contending for justice. Ideologies and theologies of social justice in the Old Testament, T\&T Clark, London.

Huey, F.B. Jr, 1993, Jeremiah, lamentations, Broadman Press (The New American Commentary), Nashville.

Jones, D.R., 1992, Jeremiah, Eerdmans (New Century Bible Commentary), Grand Rapids. 23. Maier (2008:24) argued that Jeremiah $2: 8 ; 8: 8$ and $31: 33$ allude to the Torah as
a written code of law. He regarded Jeremiah as a teacher of the Torah, showing people how to amend their ways (2008:26). 
Kühlewein, J., 1971, 'gbr', in E. Jenni \& C. Westermann (eds.), Theologischer Handwörterbuch zum Alten Testament (THAT), pp. 399-402, Chr. Kaiser Verlag, München.

Lundbom, J.R., 1999, Jeremiah 1-20, Doubleday (The Anchor Bible), New York.

Maier, C., 2002, Jeremia als Lehrer der Tora. Soziale Gebote des Deuteronomiums in Fortschreibungen des Jeremiabuches, Vandenhoeck \& Ruprecht, Göttingen.

Maier, C.M., 2008, 'Jeremiah as teacher of the Torah', Interpretation 22-32.

McKane, W., 1986, A critical and exegetical commentary on Jeremiah, T \& T Clark (ICC), Edinburgh.

O'Day, G.R., 1990, 'Jeremiah 9:22-23 and 1 Corinthians 1:26-31. A study in intertextuality', Journal of Biblical Literature 109(2), 259-267.

Oosterhoff, B.J., 1990, Jeremia, Uitgeversmaatchappij JH Kok (COT), Kampen.

Rudolph, W., 1968, Jeremia, 3, verbesserde Aufl, JCB Mohr, Tübingen.

Saebo, M., 1976, 'שכh hi. Einsichtig sein', in E. Jenni \& C. Westermann (eds.), Theologisches Handwörterbuch zum Alten Testament, pp. 824-828, Chr. Kaiser Verlag (THzAT), München.

Schmidt, W.H., 2008, Das Buch Jeremia. Kapitel 1-20, Vandenhoeck \& Ruprecht (ATD 20), Göttingen.
Schmitz, E.D., 1971, 'Knowledge', in C. Brown (ed.), The new international dictionary of New Testament theology, pp. 392-406, The Paternoster Press, Exeter.

Schottroff, W., 1971, 'jd erkennen', in E. Jenni \& C. Westermann (eds.), Theologisches Handwörterbuch zum Alten Testament, pp. 682-701, Chr. Kaiser Verlag (THzAT), München.

Schreiner, J., 1981, Jeremia 1-25,14, Echter Verlag (Die Neue Echter Bibel), Würzburg.

Soza, J.R., 2005, "Knowing the Lord": Moral theology in the Book of Jeremiah', Unpublished thesis, University of South Africa.

Stoebe, H.J.,1971, 'דøח Güte', in E. Jenni \& C. Westermann (eds.), Theologisches Handwörterbuch zum Alten Testament, pp. 600621, Chr. Kaiser Verlag (THzAT), München.

Stulman, L., 2005, Jeremiah, Abingdon Press (Abingdon Old Testament Commentaries), Nashville.

Thompson, J.A., 1980, The book of Jeremiah, Eerdmans, Grand Rapids.

Weiser, A., 1969, Das Buch Jeremia, Vanderhoeck \& Ruprecht (ATD), Göttingen.

Williams, D.H.H. III, 2002, 'Of rags and riches: The benefits of hearing Jeremiah 9:23-24 within James 1:9-11', Tyndale Bulletin 53(2), 273-282.

Wolff, H.W., 1993, Amos. Dodekapropheten 2, Neukirchener Verlag (BK XLV/8), Neukirchen-Vluyn. 